\title{
STUDY ON BULLYING AND ITS EFFECTS WITH STUDENTS IN FUNDAMENTAL EDUCATION IN SCHOOL OF INTERIOR PAULISTA
}

\author{
Caio Cavenaghi Dias' ${ }^{1}$, Eduarda Ferreira de Queiroz ${ }^{1}$, Joyce Teles Junqueira' ${ }^{1}$, Laura Fernandes da Cunha \\ Carvalho" $^{1}$, Laysa Bianca Menezes Barbosa1 ${ }^{1}$, Lucas Ferreira Borges ${ }^{1}$, Natália Assis Marcelino da Silva ${ }^{1}$, \\ Natália Oliveira Rodrigues ${ }^{1}$, Natália Rottolo Garcia1, Rafael Gago Paulino¹, Idiberto José Zotarelli Filho*2 \\ and Uderlei Doniseti Silveira Covizzi ${ }^{1}$
}

\author{
1University Center of Votuporanga-SP- Medical Course - UNIFEV, Brazil; \\ ${ }^{2}$ Facultyof Medicine - FACERES - São José do Rio Preto - SP, Brazil
}

\begin{tabular}{ll}
\hline ARTICLE INFO & ABSTRACT \\
\cline { 2 - 2 } $\begin{array}{l}\text { Article History: } \\
\text { Received } 28^{\text {th }} \text { March, } 2020\end{array}$ & $\begin{array}{l}\text { Bullying is defined as a set of intentional aggressions practiced in an unequal power relationship, } \\
\text { bringing numerous psychological, physical, social, and learning consequences for the individual. } \\
\text { Received in revised form } \\
19^{\text {th }} \text { April, } 2020\end{array}$ \\
$\begin{array}{l}\text { Accepted } 02^{\text {nd }} \text { May, } 2020 \\
\text { In addition, it affects } 43 \% \text { of children and youth in Brazil, according to the UN. In view of this } \\
\text { wide scope, it must be combated in order to provide a better quality of life for students. The aim } \\
\text { of the project is to collect data on the number of aggressors and victims, the most frequent } \\
\text { locations, the most affected gender, the most common age, the most frequent type of bullying, as } \\
\text { well as its effect on the lives of young people. The project's methodology is based on dynamics } \\
\text { for the establishment of bonds and questionnaires for the collection of data on the students' } \\
\text { experience in relation to bullying. The results obtained showed that more than half revealed that } \\
\text { they hallying. Empathy. Education. }\end{array}$ & $\begin{array}{l}\text { group. Furthermore, they suggested that the stimulus of empathy in children reflected positively } \\
\text { on their lives and on society as a whole. Therefore, the need to encourage respect since childhood } \\
\text { is concluded, in order to minimize these practices and their consequences. }\end{array}$ \\
$\begin{array}{l}* \text { Corresponding author: } \\
\text { Idiberto José Zotarelli Filho, }\end{array}$ &
\end{tabular}

Copyright (C) 2020, Caio Cavenaghi Dias et al. This is an open access article distributed under the Creative Commons Attribution License, which permits unrestricted use, distribution, and reproduction in any medium, provided the original work is properly cited.

Citation: Caio Cavenaghi Dias, Eduarda Ferreira de Queiroz, Joyce Teles Junqueira, Laura Fernandes da Cunha Carvalho et al. "Study on bullying and its effects with students in fundamental education in school of interior paulista", International Journal of Development Research, 10, (06), 3687336877.

\section{INTRODUCTION}

Bullying is defined as a set of intentional, repetitive, and practiced aggressions in an unequal power relationship between victims and aggressors [1]. The term is classified into subtypes as physical; verbal; moral, social or psychological; material; and cyberbullying. It can be manifested in three ways, direct, indirect, or cyberbullying [2]. According to UNICEF, half of the adolescents worldwide are victims of violence in the school environment. Given its importance, it is essential to understand how students and teachers face and understand the phenomenon of bullying to develop and judge prevention strategies appropriate to the reality of the community. Among the risk factors for the manifestation of bullying, there are the psychological and social spheres, which are based on school hierarchies and the absence or presence of an authoritarian personality, as well as responsibility [3].
One can cite feelings of helplessness, apathy, prejudice, and formation of groups whose interest is to affect, in some way, the self-esteem of the colleague. Also, there is an absence of solidary values, anxiety, revolt, self-guilt, individualism, and competitive ethics [4]. Also, it contributes to victimization, feeling lonely, not having friends, having insomnia, missing classes, suffering physical violence in the family, and having a mother with low education [5]. According to the IBGE National School Health Survey, approximately $15 \%$ of ninthgrade students have already left school, at least one day, in the 30 days before the survey, because they feel insecure on the way between home and school [5]. The consequences can cause psychological symptoms, such as school failure, anxiety, insecurity, and low self-esteem [6]. Also, children who suffered bullying practices had nocturnal enuresis, difficulty sleeping, headache, abdominal pain, hyperventilation, anorexia, and bulimia [7]. Also, those children who bullied and 
promoted bullying were also psychologically disturbed, which included depression in primary school [6]. Through this, it can be said that the prevention of bullying corroborates the Federal Constitution of 1988 whichensures education as a right of all, aiming at the full development of the human person, which is fundamental for the exercise of their citizenship. Law No. 13,185 of November 6, 2015, instituted the Program to Combat Systematic Intimidation (Bullying) [8]. Among the objectives of the law is to prevent and combat the practice of systematic intimidation throughout society; training teachers and pedagogical teams to implement discussion, prevention, guidance, and problem-solving actions; psychological, social and legal assistance to victims and aggressors; avoiding, as much as possible, the punishment of aggressors, favoring alternative mechanisms and instruments that promote effective accountability and the change of hostile behavior [9]. Also, the Health at School Program (PSE), instituted by Presidential Decree No. 6,286 of December 5, 2007, results from the integrated work between the Ministry of Health and the Ministry of Education, to expand specific health actions to public school students, seeking the integration of health and education for health promotion, prevention and care $[10,11]$. This enables integration between medical students at the Centro Universitário de Votuporanga and students from CEM Professor Clary BrandaoBertoncini.

Children's socialization consists of a process in which they learn and assume social norms and values through interaction with their surroundings. It is at that moment that they absorb, without question, the influences with which they come into contact [12]. Thus, it is essential to approach bullying and its effects at this time in life. The dynamics were intended to encourage empathy and harmony, being fundamental for preventing violence in the school environment, aiming at preventing acts of aggression by bullying, as this can cause risks to them, as they feel rejected and excluded from the environment. the school they live in. Through them, information was obtained on the number of aggressors and victims, the place where such aggression occurs most, male or female predominance, the age at which the actions were initiated and the types of aggressions, which may be physical, verbal, cyberbullying and writing, occurring directly or indirectly.

\section{MATERIALS AND METHODS}

Study design: The present study followed a retrospective longitudinal cohort model, following the STROBE (Strengthening the Reporting of Observational Studies in Epidemiology) rules [13]. The present study followed an Epidemiological / Observational model and was carried out by the Unifev students of the Medical course, from the 3rd period, through dynamics in five meetings that were held with 34 students between 9 and 14 years of the 4th and 5th year of elementary school I from CEM school Prof. Clary BrandãoBertoncini in which cases of bullying were identified. In the first meeting, the link between students and students was established, and in the other meetings, quantitative and qualitative research was carried out to collect data on childhood bullying during the school period, as well as encouraging empathy and respect. A dynamic was established to establish the bond, called the Ball Game, in which during the activity the participants made a circle and threw the ball to another participant who, upon receiving it, spoke his name and a characteristic of himself aloud. The game was repeated until everyone had introduced themselves. After that, a questionnaire was applied to the students to identify the forms, the context, the place, the age range in which it occurs, with whom it occurs, and the effects caused by both the victim and the aggressor and testimony about the bullying. The living environment and its influence were also identified. Finally, the students discussed orally the subtypes of bullying and its effects [14,15]. PEACE dynamics were also carried out. Initially, the word PEACE was written on a sulfite sheet, in which the students wrote around them the feelings, synonyms, or characteristics that this word causes in them. Subsequently, there was a reflection on the data collected on the sheet. Then, the students wrote down non-PEACE situations, which were reflected along with the PEACE situation, to choose the five biggest causes, placing in order according to the negative effects that could cause damage. Soon after, the students pointed out the postures of overcoming and guiding each cause [16]. Inclusion dynamics were carried out, in which at the firstmoment bond paper was distributed on which they designed a sun with seven radios or more. They wrote their names in the center of the sun and each ray, something of themselves that they would like to share as a taste, personal characteristics, fears, feelings, and dreams of life. Then, they formed a circle for each one to read what he put in the rays of the sun. Finally, a collective interpretation was made of what was important, the discoveries, and the difficulties experienced. In the second moment, three people were chosen to leave the room. The other participants were instructed to provide an experience of exclusion with the three who left the room avoiding them at the moment of hugging or dancing. Upon returning to the room, a song was put on inviting everyone to dance in pairs or trios, excluding students who left the room. Finally, the students reflected with the students, who suffered and practiced exclusion, about the feeling at this moment, and the damage it can do to everyone's life [16].

A questionnaire was also applied to students and teachers, obtaining data on their view of bullying, in which more than one alternative could be checked. In addition to collecting opinions on attitudes taken by the school to prevent bullying, punishments by the aggressor, and suggestions for prevention $[17,18]$. Finally, there was the dynamics of the workshop on defects/stores of virtues. The students took surprise bags with cards of virtues, such as courage, generosity, honesty, selfdiscipline, kindness, compassion, loyalty, patience, selfconfidence, tolerance, used at the end of the dynamic. Initially, students wrote on paper about self-attitudes that affect interpersonal relationships and would like to change them. Such attitudes could consist of prejudice, fear of challenges, lack of initiative, lack of commitment to performing tasks, sadness, loneliness, fear of rejection, fear of making mistakes, dependence on others, and shyness. After that, a volunteer started the activity, choosing a gift with virtues previously established by the students, which he exchanged for one of the attitudes that he disapproves of and was expressed on paper. Finally, they expressed their satisfaction with the exchange $[18,19]$.

\section{RESULTS}

The results achieved through the questionnaire, carried out in the 1 st meeting, with the students showed that $53 \%$ of them had already suffered this type of aggression, and in $62 \%$ of the cases the duration was only 1 day, $6 \%$ lasted 1 month, $25 \%$ one year and $7 \%$ more than one year (GRAPH 1). In the 
reported cases, $53 \%$ of the victims suffered aggression when they were in a group of people. Regarding the type of reaction, it was observed that $22 \%$ of the attacked did not share this aggression with anyone, while $78 \%$ communicated, with $56 \%$ reporting to their parents, $11 \%$ to friends, and $28 \%$ to another person in their relationship (GRAPH 2). Of the total respondents, $16 \%$ of the victims claimed to have suffered physical bullying, 39\% verbal, 13\% moral or psychological, $6 \%$ written, and $26 \%$ material (GRAPH 3). Among the students who answered the questionnaire, 50\% said they knew the term cyberbullying and $32 \%$ said they had already suffered threats or insults through social networks. When asked about their feelings when they saw their neighbor being bullied, $64 \%$ reported feeling sorry, 33\% angry and 3\% feel nothing, as they have never been through the situation. They also reported that, when witnessing such a situation, $32 \%$ were not involved, $68 \%$ defended the victim and no one helped in the aggression. Regarding bullying at school, $22 \%$ of respondents never witnessed any act, 70\% have witnessed it, 8\% did not know how to answer. Respondents reported the presence of campaigns, debates, and information on the topic promoted by the school, and $73 \%$ of students believe that these activities help to avoid bullying, $21 \%$ believe they do not and $6 \%$ did not respond.

\section{TIME DURING THE BULLYING SITUATION BETWEEN BOYS AND GIRLS}

aDay $1 \mathrm{MONTH}=1$ YEAR morethan a year

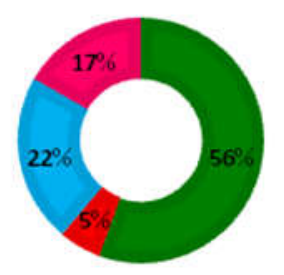

Graph 1. Refers to the duration of bullying among students. Data were collected from the responses to the NEPSO questionnaire applied during the 1 st meeting

\section{WHO REPORTED THE BULLYING EPISODE}

Mother and Father Friend (A) $\mathbf{a}$ Other people Did not answer

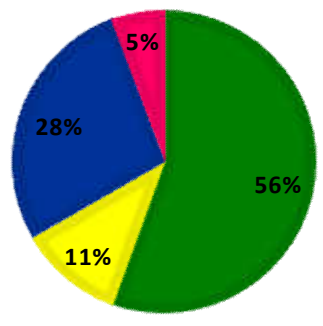

Graph 2. Refers to those who reported the bullying episode. Data were collected from the responses to the NEPSO questionnaire applied during the 1st meeting

The data obtained, from the questionnaire carried out in the 4th meeting with students and the pedagogical team, show that $64 \%$ of male students believe that the desire to die and the desire not to go to school are the main consequences for victims of bullying, while $50 \%$ of females indicate the desire not to go to school and $45 \%$ are afraid (GRAPH 4). When asked about the consequences of bullying for the aggressor, it was found that in males, $57 \%$ pointed to sadness and the desire to hurt their colleagues, had a higher proportion; while among women, $30 \%$ demonstrated that the aggressor felt superior to others at school (GRAPH 5). Finally, teachers responded unanimously that the most used practices at school to prevent these aggressive behaviors are to suspend the aggressors and talk to them (GRAPH 6).

\section{TYPES OF BULLYING BETWEEN BOYS AND GIRLS WHO HAVE ALREADY SUFFERED BULLYING

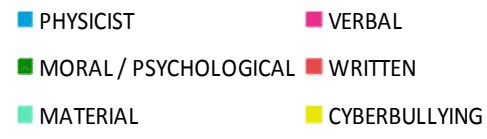

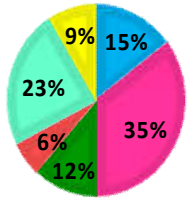

Graph 3. Refers to the type of bullying they suffered. Data werecollectedfromthe responses tothe NEPSO questionnaireappliedduringthe 1st meeting.

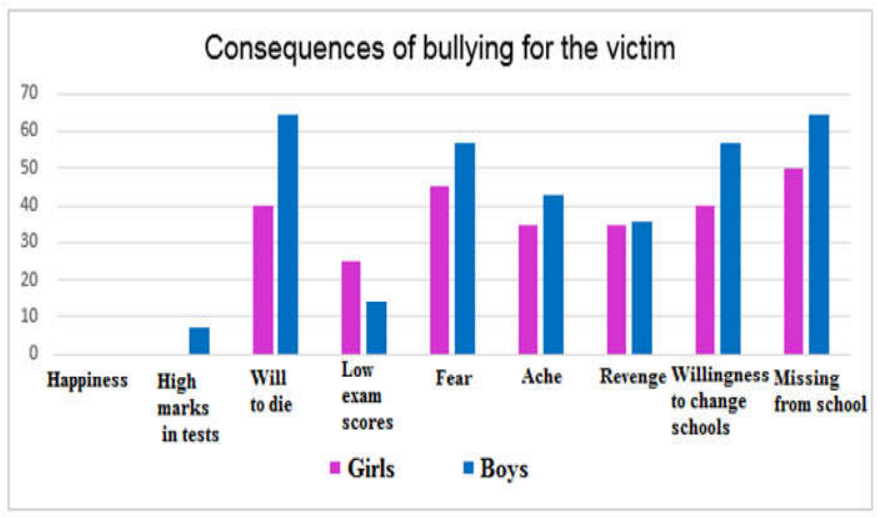

Graph 4. Refers to the consequences of bullying for the victim, being collected from the answers to questionnaire 2 applied during the 4th meeting

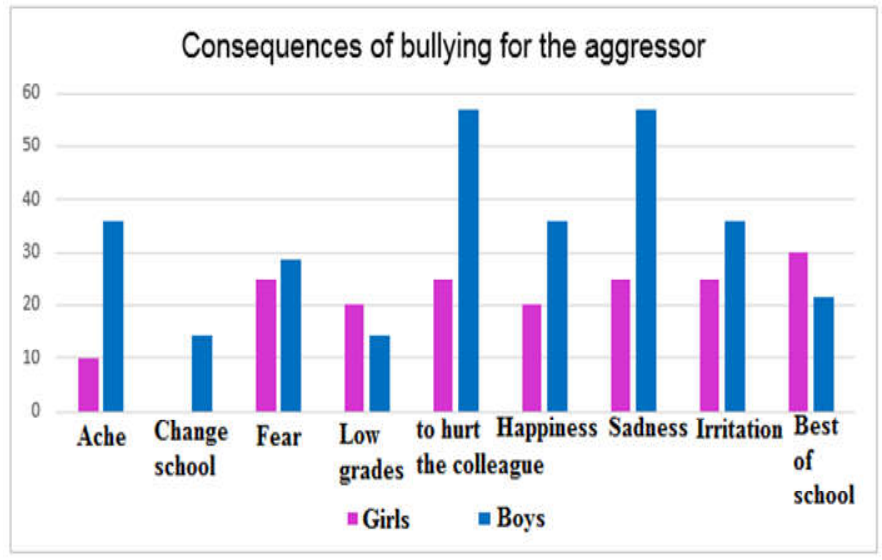

Graph 5. Refers to the consequences of bullying for the aggressor, being collected from the answers to questionnaire 2 applied during the 4th meeting 


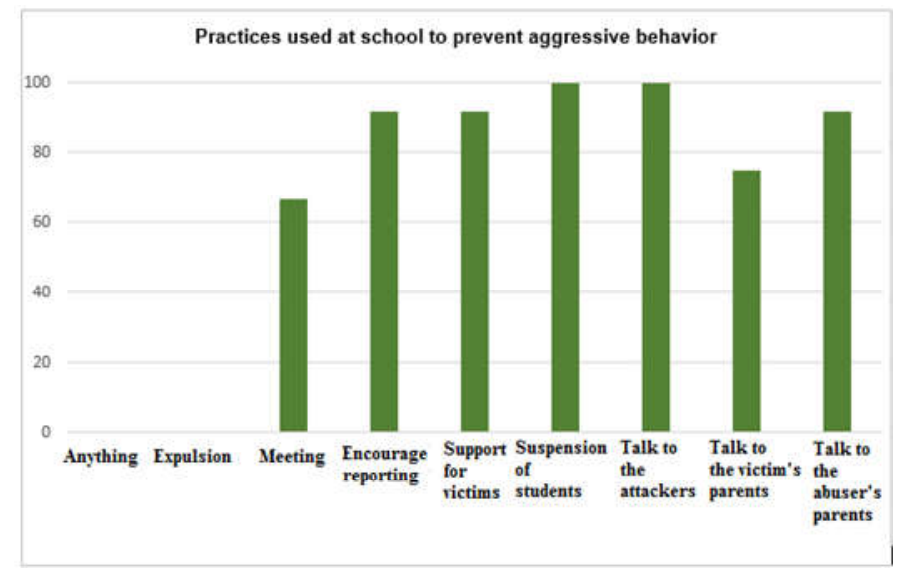

Graph 6. Refers to the practices used to prevent bullying at school, being collected from the responses to questionnaire 2 applied during the 4th meeting

\section{DISCUSSION}

The results demonstrated that bullying is prevalent in the school environment, as observed in other studies, showing that these episodes occur with the same frequency among boys and girls, in contradiction with the literature that reports the occurrence four times higher in boys [1]. Also, it was found in the work that there is emphasis on verbal bullying, as well as the literature points out [2]. Furthermore, it was demonstrated with the analysis of the data collected that the professors interviewed claimed that the main preventive measure for recurrence of aggressive behaviors is the conversation with the students, attention to the aggressors and, when necessary, firm stance, as well as was observed by research [3]. Also, it was observed that the main feelings when seeing others suffering bullying were pity and anger, as shown in the bibliography [20]. It was also analyzed that most of the bullying observers helped the victim, which contradicts the literature that demonstrates that the observers reacted passively as shown by the authors, also fearing suffering the aggression [21,22]. Finally, it was found that most of the victims shared the aggression with their parents, which was against what was expected by the group. From this, it is concluded that bullying is present in the lives of the vast majority of children and young people, as well as that education professionals and students recognize the countless physical, mental and social consequences in the lives of the victims. With that, the stimulus of empathy and respect was shown to be fundamental and effective, aiming to avoid aggressive acts and, with this, to improve the quality of life of the child and society [22].

Also, a study aimed to examine whether concerns about bullying mediate the relationship between the school climate and the victimization of bullying by students, as well as aggressive behavior. The data were from a sample of 301 students in grades 6 through 8 at two predominantly minority schools in a large US metropolitan area. The results of the structural equation modeling (SEM) analysis of initialization indicate that, for male students, a higher level of perceived anti-bullying school climate was negatively associated with bullying reporting concerns, while reporting concerns subsequently were positively associated with victimization and aggressive bullying behavior. For the students, the perceived school climate was not associated with concerns about reporting bullying, but the latter were also positively associated with victimization by bullying and aggressive behavior. Therefore, concerns about communication about bullying mediated the association between the perceived school climate and victimization by bullying, as well as aggressive behavior towards male students, but not towards women. The findings suggest the importance of strengthening the school's anti-bullying climate to help students overcome the concerns of bullying reports to achieve effective results. The gender difference in the associations between school climate and concerns about bullying reports may reflect the variation in the types of bullying experienced by male and female students, which requires attention to the development of anti-bullying strategies that take into account differences in gender and address various types of bullying [23]. Besides, another study investigated whether bullying among students is associated with symptoms of post-traumatic stress disorder (PTSD) and whether the associations are comparable to other traumatic events leading to PTSD. Data were collected from 219 German children and adolescents: 150 students from the sixth to the tenth year and 69 patients from a PTSD clinic as a comparison group. The results showed that $69(46.0 \%)$ students in the school sample suffered bullying, $43(28.7 \%)$ moderately, and 26 (17.3\%) severely. About 50\% of the severe bullying group reached the critical cutoff point for suspected PTSD. Although scores for PTSD symptoms were significantly higher in students who were bullied than they were not bullied, no significant differences were found between patients in the PTSD clinic and students who were severely bullied. Therefore, the results suggest that bullying at school is highly associated with PTSD symptoms. Thus, preventing bullying at school can reduce traumatic experiences, and the consequent development of PTSD [24].

Also, to determine the prevalence of bullying in Brazilian schools and to analyze its association with physical activity and body image, data from 51,192 students were collected. Boys are more intimidated (7.2\%) and are also more intimidating than girls $(\mathrm{p}<0.01)$. Regarding body image, $26 \%$ of the girls considered themselves thin or very thin $(p \leqslant 0.01)$. For boys, we observed associations between the variable of being treated well by classmates and race. Bullying was associated with the mother's education. The data show the need for intersectoral actions based on educational policies and practices that can reduce and prevent bullying in schools [25]. Finally, a study aimed to examine the relationship between being a victim of bullying and depressive symptoms, exploring whether the three sources of social support mentioned moderated this association and examining gender differences in the moderating effects of social support on depressive symptoms associated with bullying among Chinese high school students.

A total of 1,252 students were selected from three high schools in Zhenping County, Henan Province, China. The results suggest that victimization by bullying is significantly associated with depressive symptoms among high school students. In addition, it was found that only school-type social support had a moderating effect on depressive symptoms. Those who were bullied, but with high levels of school support, had lower levels of depressive symptoms than those with less school support. However, the moderating effects of this support were found only for girls, not for boys. This study empirically supports that programs designed to increase social support for students of teachers and classmates can help protect high school students from depressive symptoms [26]. 


\section{Acknowledgments}

The elaboration of the project would not be possible without the help and commitment of several people. First of all, we would like to thank the Centro Universitário de Votuporanga, for providing us with the knowledge and commitment necessary to carry out the project. We also thank Vínicius Cinelli Alves, pedagogical coordinator of the school in which the project was carried out, as well as the teachers of the school for welcoming and supporting us in carrying out the project. We thank our parents who have always supported us and stimulated the search for quality knowledge and education.

Competing interests: The authors no have competing interests.

\section{REFERENCES}

Brasil. Constituição (1988). Constituição da República Federativa do Brasil. Brasília: Senado Federal, 1988. Acesso em: 27 de março de 2019.

Brasil. Diário Oficial Da União. República Federativa do Brasil. Lei $\mathrm{N}^{\circ}$ 13.185, de 06 de novembro de 2015. Brasília, DF. Disponível em: http:/www.planalto.gov.br/ ccivil_03/_ato2015-2018/2015/lei/113185.htm. Acesso em: $2 \overline{7}$ de março de 2019.

Brasil. Lei $\mathrm{n}^{\mathrm{o}}$ 8.069, de 13 de julho de 1990. Estatuto da Criança e do Adolescente. Diário Oficial da União, Brasília, DF. 16 de julho de 1990. Seção 1, página 13563.

Brasil. Ministério da Saúde. Cadernos de AtençãoBásica. Saúde na Escola. Secretaria de Atenção à Saúde. Departamento de AtençãoBásica - Brasília: Ministério da Saúde, 2009. Disponível em: <http://189.28.128.100/ dab/docs/publicacoes/cadernos_ab/abcad24.pdf $>$ Acesso em: 27 de março de 2019.

Catini, Nilza. Problematizando o "bullying" para a realidade brasileira. Disponível em: <http://www.bibliotecadigital. puc-campinas.edu.br/tde_arquivos/6/TDE-2012-0315T050938Z-1719/Publico/Nilza\%20Catini.pdf> Acesso em: 13 de março de 2019.

Elm EV, Altman DG, Egger $M$, et al, for the STROBE Initiative. The Strengthening the Reporting of Observational Studies in Epidemiology (STROBE) Statement: Guidelines for Reporting Observational Studies. PLoS Med. 2007, 4:296. http://dx.doi.org/10.1371/journal.pmed.0040296.

Garcia AC, Sousa R, Varela A, Monteiro L. Bullying, physical activity, and body image among Brazilian students. J Health Psychol. 2019 Nov 1:1359105319884598. doi: $10.1177 / 1359105319884598$.

Guo J, Li M, Wang X, Ma S, Ma J. Being bullied and depressive symptoms in Chinese high school students: The role of social support. Psychiatry Res. 2019 Nov 4:112676. doi: 10.1016/j.psychres.2019.112676.

Instituto Paulo Montenegro. Questionário NEPSO - tema bullying, 2002. Disponível em: <www.nepso.net/busca/ projeto $>$ Acesso em: 10 de abril de 2019.

Kaltiala-Heino R, Rimpelä $\quad M$, Marttunen $\quad$ M, Rimpelä A, Rantanen P.Bullying, depression, and suicidal ideation in Finnish adolescents: school survey. BMJ. 1999 Aug 7;319(7206):348-51.
Kumpulainen K, Räsänen E, Henttonen I, Almqvist F, Kresanov K, Linna SL, Moilanen I, Piha J, Puura $\mathrm{K}$, Tamminen $\mathrm{T}$. Bullying and psychiatric symptoms among elementary school-age children. Child Abuse Negl. 1998 Jul;22(7):705-17.

Leite Junior,P.G. da S. Ética das virtudes, pág 15, 2012.

Lopes, Neto. Bullying - comportamento agressivo entre estudantes. J Pediatria (Rio J). 2005;81(5 Supl): S164S172.

Mayer, Canísio - O poder de transformação: Dinâmicas de grupos. Campinas, Papirus editora, pág. 99, 2007.

Miranda, S - Oficina de Dinâmica de Grupos para Empresas, Escolas e grupos comunitários. $1^{\mathrm{a}} \mathrm{Ed}, \mathrm{Vol} .3$, Campinas, Papirus editora, 2017.

Ossa FC, Pietrowsky R, Bering R, Kaess M. Symptoms of posttraumatic stress disorder among targets of school bullying. Child Adolesc Psychiatry Ment Health. 2019 Nov 9;13:43. doi: 10.1186/s13034-0190304-1. eCollection 2019.

Pinto, M., Sarmento, M. J. As Crianças: contextos e identidades. Braga: Centro de Estudos da Criança/Universidade do Minho, 293 páginas. 1997, ISBN: 9729732310.

Ruzany,M,H. Oficinas de ideias. Manual de Dinâmicas. Rio de Janeiro, pág. 16, 2003.

Santos, M. M., Perkoski, I. R., Kienen, N.; Bullying: Atitudes, Consequências e Medidas Preventivas na Percepção de Professores e Alunos do Ensino Fundamental, 2015, 23, 4, 2015.

Silva, J.; Mello, F.; Oliveira, W.; Prado, R.; Silva, M.; Malta, D. Vitimização por bullying em estudantes brasileiros: resultados da pesquisa nacional de saúde escolar (PENSE). Texto contexto - enferm. Florianópolis, 2018, v.27, n. 3, e0310017.

Sociedade Brasileira De Pediatria. Bullying, 2017. Disponível em: http://www.sbp.com.br/fileadmin/user_upload/ 20032d-GPA_-_Bullying.pdf. Acesso em: 20 de março de 2019.

Stanley IH, Horowitz LM, Bridge JA, Wharff EA, Pao M, Teach SJ. Bullying and suicide risk among pediatric emergency department patients. PediatrEmergCare. 2016 Jun [cited 2017 Feb 23];32(6):347-51.

Unicef - ONU; Metade dos adolescentes do mundo são vítimas de violência na escola: Disponível em: $<$ https://nacoesunidas.org/unicef-metade-dosadolescentes-no-mundo-sao-vitimas-de-violencia-naescola/> Acesso em: 27 de março de 2019.

Vizini, S. Evidências de validação do questionário de bullying de Olweus versão vítima e versão agressor para adolescentes brasileiros, 2017. Disponível em: $<$ http://hdl.handle.net/10183/178254 > Acesso em: $10 \mathrm{de}$ abril de 2019.

Williams K, Chambers M, Logan S, Robinson D. Association of common health symptoms with bullying in primary school children. BMJ 1996; 313: 17-19.

Zhang S, Mulhall PF, Flowers N, Lee NY. Bullying Reporting Concerns as a Mediator Between School Climate and Bullying Victimization/Aggression. J Interpers Violence. 2019 Nov 26:886260519889926. doi: $10.1177 / 0886260519889926$. [Epub ahead of print] 